\title{
Review
}

\section{A Systematic Review and Meta-Analysis of Immunoglobulin G Abnormalities and the Therapeutic Use of Intravenous Immunoglobulins (IVIG) in Autism Spectrum Disorder}

\author{
Daniel A Rossignol 1,*(i) and Richard E Frye ${ }^{2}$ (1) \\ 1 Rossignol Medical Center, 24541 Pacific Park Drive, Suite 210, Aliso Viejo, CA 92656, USA \\ 2 Barrow Neurological Institute at Phoenix Children's Hospital, 1919 E Thomas Rd, Phoenix, AZ 85016, USA; \\ rfrye@phoenixchildrens.com \\ * Correspondence: rossignolmd@gmail.com; Tel.: +321-259-7111
}

Citation: Rossignol, D.A; Frye, R.E A Systematic Review and Meta-Analysis of Immunoglobulin G Abnormalities and the Therapeutic Use of Intravenous Immunoglobulins (IVIG) in Autism Spectrum Disorder. J. Pers. Med. 2021, 11, 488. https:// doi.org/10.3390/jpm11060488

Academic Editor: Marco Costanzi

Received: 22 April 2021

Accepted: 26 May 2021

Published: 30 May 2021

Publisher's Note: MDPI stays neutral with regard to jurisdictional claims in published maps and institutional affiliations.

Copyright: (c) 2021 by the authors. Licensee MDPI, Basel, Switzerland. This article is an open access article distributed under the terms and conditions of the Creative Commons Attribution (CC BY) license (https:// creativecommons.org/licenses/by/ $4.0 /)$.

\begin{abstract}
Autism spectrum disorder (ASD) is a neurodevelopmental disorder affecting approximately $2 \%$ of children in the United States. Growing evidence suggests that immune dysregulation is associated with ASD. One immunomodulatory treatment that has been studied in ASD is intravenous immunoglobulins (IVIG). This systematic review and meta-analysis examined the studies which assessed immunoglobulin $\mathrm{G}$ (IgG) concentrations and the therapeutic use of IVIG for individuals with ASD. Twelve studies that examined IgG levels suggested abnormalities in total IgG and IgG 4 subclass concentrations, with concentrations in these IgGs related to aberrant behavior and social impairments, respectively. Meta-analysis supported possible subsets of children with ASD with low total IgG and elevated IgG 4 subclass but also found significant variability among studies. A total of 27 publications reported treating individuals with ASD using IVIG, including four prospective, controlled studies (one was a double-blind, placebo-controlled study); six prospective, uncontrolled studies; 2 retrospective, controlled studies; and 15 retrospective, uncontrolled studies. In some studies, clinical improvements were observed in communication, irritability, hyperactivity, cognition, attention, social interaction, eye contact, echolalia, speech, response to commands, drowsiness, decreased activity and in some cases, the complete resolution of ASD symptoms. Several studies reported some loss of these improvements when IVIG was stopped. Meta-analysis combining the aberrant behavior checklist outcome from two studies demonstrated that IVIG treatment was significantly associated with improvements in total aberrant behavior and irritability (with large effect sizes), and hyperactivity and social withdrawal (with medium effect sizes). Several studies reported improvements in pro-inflammatory cytokines (including TNF-alpha). Six studies reported improvements in seizures with IVIG (including patients with refractory seizures), with one study reporting a worsening of seizures when IVIG was stopped. Other studies demonstrated improvements in recurrent infections, appetite, weight gain, neuropathy, dysautonomia, and gastrointestinal symptoms. Adverse events were generally limited but included headaches, vomiting, worsening behaviors, anxiety, fever, nausea, fatigue, and rash. Many studies were limited by the lack of standardized objective outcome measures. IVIG is a promising and potentially effective treatment for symptoms in individuals with ASD; further research is needed to provide solid evidence of efficacy and determine the subset of children with ASD who may best respond to this treatment as well as to investigate biomarkers which might help identify responsive candidates.
\end{abstract}

Keywords: autism spectrum disorder; immunoglobulin G; intravenous immunoglobulin

\section{Introduction}

Autism spectrum disorder (ASD) is a neurodevelopmental disorder which is behaviorally defined by impairments in social communication and the presence of repetitive and restrictive behaviors. ASD affects approximately $2 \%$ of children in the United States [1]. Despite decades of research, the etiology and treatment of children with ASD is still very 
incomplete. This has resulted in a minority of children reaching optimal outcomes with many manifesting symptoms into adulthood and resulting in substantial economic and societal costs [2].

A number of medical comorbidities have been reported in ASD including mitochondrial dysfunction [3], sleep disorders [4], immune related problems [5], gastrointestinal abnormalities [6], inflammation [7], and epilepsy [8]. Addressing these comorbid conditions has the potential to improve the ability to function and the quality of life of children with ASD and their families [9]. One of the more recent promising areas of research is dysfunction of the immune system [10], which is a potential target for treatment.

Several lines of evidence link immune abnormalities to ASD. Family history of atopic [11] and autoimmune [12] disease is associated with ASD. Maternal immune activation during pregnancy has been shown to be associated with an increase in risk of ASD in the offspring in human [13] and animal studies [14]. Individuals with ASD demonstrate specific human leukocyte antigen risk alleles that put them at risk for immune dysfunction [15]. Elevations in specific monocyte cytokine profiles have been associated with ASD $[16,17]$ and specific patterns of inflammatory cytokines have been identified in the cerebrospinal fluid and brain in individuals with ASD [18]. Autoantibodies to the brain [19] and other important proteins such as the folate receptor alpha [20] also appear to be associated with ASD.

Children with ASD also appear to be at increased risk for clinical immune disorders. Some of the immune-related problems reported in ASD include common variable immunodeficiency (CVID), hypogammaglobulinemia (i.e., low total Immunoglobulin G (IgG)) [21] and specific polysaccharide antibody deficiency (SPAD) [22]. One study reported that lower levels of $\operatorname{Ig} G$ were associated with more severe aberrant behaviors in children with ASD [23]. A number of studies have reported on the use of intravenous immunoglobulin (IVIG) in ASD to treat immune-related problems [21]. Some of the medical comorbidities reported in ASD might also improve with the use of IVIG. For example, IVIG has been shown to have anti-seizure properties [24-26] and anti-inflammatory effects [27-30]. The anti-inflammatory effects of IVIG are observed at higher doses of IVIG (i.e., 2 grams $/ \mathrm{kg}$ ) for inflammatory and autoimmune disorders [31].

This paper is a systematic review and meta-analysis examining the evidence for abnormal IgG concentrations and the therapeutic use of IVIG in ASD. Adverse events (AEs) are also collated. This study demonstrates that IVIG is a promising and potentially effective treatment for symptoms in individuals with ASD, but further research is needed to provide solid evidence of efficacy and determine the subset of children with ASD who may best respond to this treatment, as well as to investigate biomarkers which might help identify responsive candidates.

\section{Materials and Methods}

\subsection{Search Strategy}

A prospective protocol for this systematic review was developed a priori, and the search terms and selection criteria were chosen in an attempt to capture all pertinent publications. A computer-aided search of PUBMED, Google Scholar, EmBase, Scopus and ERIC databases from inception through March 2021 was conducted to identify pertinent publications using the search terms 'autism', 'autistic', 'Asperger', 'ASD', 'pervasive', and 'pervasive developmental disorder' in all combinations with the terms 'IVIG', 'IgG', 'immunoglobulin', 'immunoglobulins', 'globulin', 'intravenous immunoglobulin', 'gamma globulin' and 'immunodeficiency.' The references cited in identified publications were also searched to locate additional studies. Supplementary Figure S1 depicts the publications identified during the search process.

\subsection{Study Selection and Assessment}

This systematic review and meta-analysis followed PRISMA guidelines [32]. The PRISMA Checklist and Flowchart can be found in Supplementary Table S1. One reviewer 
screened titles and abstracts of all potentially relevant publications. Studies were initially included if they (1) involved individuals with ASD; and (2) reported on the use of IVIG or reported IgG concentrations. Animal models were excluded. Abstracts or posters from conference proceedings were included if published in a journal. Articles were excluded if they: (1) Did not involve humans (for example, cellular models); or (2) did not present new or unique data (such as review articles or letters to the editor). After screening all records, 38 publications met inclusion criteria (see Supplementary Figure S1); two reviewers then independently reviewed these articles for inclusion and assessed factors such as the risk of bias. As per standardized guidelines [33], selection, performance detection, attrition, and reporting biases were considered. One study reported on IgG levels and also treatment with IVIG. Two studies reported on the use of oral immunoglobulin in ASD and were not included in the analysis $[34,35]$. One manuscript reported an ongoing double-blind placebo controlled (DBPC) crossover study which was never published and not included in the analysis [36].

\subsection{Meta-Analysis}

MetaXL Version 5.2 (EpiGear International Pty Ltd., Sunrise Beach, Queensland, Australia) was used with Microsoft Excel Version 16.0.12827.20200 (Redmond, WA, USA) to perform the meta-analysis. Mean immunoglobulin titers were pooled across studies using standard methodology [37]. Various manuscripts reported immunoglobulin concentrations in different units. For consistency we report concentrations in $\mathrm{mg} / \mathrm{dL}$. In some papers the interquartile intervals were reported rather than standard deviations. In such cases we use the estimator for estimating the standard deviation from interquartile range as defined by the Cochrane Handbook [38]. The data from this meta-analysis is available upon request to the authors.

To compare immunoglobulin titers across groups, pooled mean differences were calculated using the inverse variance heterogeneity model since it has been shown to resolve issues with underestimation of the statistical error and spuriously overconfident estimates with the random effects model when analyzing continuous outcome measures [39]. Cochran's $Q$ was calculated to determine heterogeneity of effects across studies and when significant, the $\mathrm{I}^{2}$ statistic (Heterogeneity Index) was calculated to determine the percentage of variation across studies that is due to heterogeneity rather than chance [40,41]. The Luis Furuya-Kanamori (LFK) Index derived from Doi plots were reviewed for significant asymmetries $(> \pm 2)$ in the prevalence distribution when there were 3 or more studies $[42,43]$.

Few intervention studies used quantitative standardized outcome measures, but two used the Social Responsiveness Scale (SRS) and five used the Aberrant Behavioral Checklist $(A B C)$. Of note, the social withdrawal subscale of the $A B C$ is called lethargy and inadequate eye contact in some studies, but we will refer to it as social withdrawal throughout to be consistent. Only two treatment studies contained enough details to be included in the treatment meta-analysis. Random-effects models, which assume variability in effects from both sampling error and study level differences [44,45], were used to calculate pooled standardized mean effect and pooled effect size. Effect sizes were considered small if Cohen's d' was 0.2; medium for Cohen's d' was 0.5; and large if Cohen's d' was 0.8 or higher [46].

\section{Results}

\subsection{Studies of IgG Concentrations in Autism Spectrum Disorder}

Articles examining IgG concentrations in individuals with ASD are first examined followed by studies which have reported therapeutic IVIG use in ASD.

\subsubsection{Studies on IgG Concentrations in ASD}

Twelve studies were identified that measured IgG concentrations in children with ASD (Table 1). Eight studies examined serum IgG with six using controls and two using standard reference ranges. Two studies examined serum IgG in neonates with both using controls. Two 
studies examined IgG in cerebrospinal fluid (CSF) with one using controls and one using a standard reference range. Most studies only had a modest number of participants with only four studies having a relatively large number of participants (i.e., $80+$ ).

Table 1. Studies of Immunoglobulin G Concentration in Autism Spectrum Disorder. DD = Developmental Delay, TD = Typical Developing, $\mathrm{P}=$ Prospective, $\mathrm{R}=$ Retrospective; CSF = Cerebrospinal Fluid; $\mathrm{AD}=$ Autistic Disorder; NDR = Neurodevelopmental Regression.

\begin{tabular}{|c|c|c|c|c|}
\hline Study & $\begin{array}{l}\text { Study } \\
\text { Type }\end{array}$ & $\begin{array}{l}\text { Autism } \\
\text { Group }\end{array}$ & $\begin{array}{l}\text { Control } \\
\text { Group }\end{array}$ & Outcomes \\
\hline \multicolumn{5}{|c|}{ Studies in Children Using Contemporaneous Control Groups for Comparison } \\
\hline $\begin{array}{l}\text { Croonenberghs } \\
\text { et al., } 2002 \text { [47] }\end{array}$ & $\mathrm{P}$ & 18 & $22 \mathrm{TD}$ & $\begin{array}{l}\text { Total IgG, IgG2 and IgG4 higher in ASD } \\
\text { No Difference in IgG1 and IgG3 }\end{array}$ \\
\hline $\begin{array}{l}\text { Trajkovski } \\
\text { et al., } 2004[48]\end{array}$ & $\mathrm{R}$ & 35 & $\begin{array}{l}21 \mathrm{TD} \\
\text { Siblings }\end{array}$ & $\begin{array}{l}\text { Total IgG and IgG4 higher in ASD } \\
\text { No Difference in IgG1, IgG2 and IgG3 }\end{array}$ \\
\hline $\begin{array}{c}\text { Heuer } \\
\text { et al., } 2008 \text { [23] }\end{array}$ & $\mathrm{P}$ & $\begin{array}{l}166 \text { with } \\
\text { AD } \\
27 \text { with } \\
\text { ASD }\end{array}$ & $\begin{array}{l}96 \mathrm{TD} \\
32 \mathrm{DD}\end{array}$ & $\begin{array}{c}\text { Total IgG lower in AD } \\
\text { Total IgG Inversely Correlated with Behavior }\end{array}$ \\
\hline $\begin{array}{l}\text { Enstrom } \\
\text { et al., } 2009 \text { [49] }\end{array}$ & $\mathrm{P}$ & 114 & $\begin{array}{l}96 \mathrm{TD} \\
31 \mathrm{DD}\end{array}$ & $\begin{array}{c}\text { IgG4 higher in ASD } \\
\text { No Difference in IgG1, IgG2 and IgG3 } \\
\text { IgG4 Correlated with Social Impairment }\end{array}$ \\
\hline $\begin{array}{l}\text { Spiroski } \\
\text { et al., } 2009[50]\end{array}$ & $\mathrm{R}$ & 30 & $\begin{array}{l}22 \text { TD Sibs } \\
30 \text { Moms } \\
26 \text { Dads }\end{array}$ & $\begin{array}{c}\text { No Difference in Total IgG, IgG1, IgG2, IgG3 or IgG4 } \\
\text { between ASD and TD Siblings }\end{array}$ \\
\hline $\begin{array}{l}\text { Wasilewska } \\
\text { et al., } 2012 \text { [51] }\end{array}$ & $\mathrm{P}$ & $\begin{array}{c}24 \\
\text { NDR }\end{array}$ & $14 \mathrm{TD}$ & No Difference in Total IgG \\
\hline \multicolumn{5}{|c|}{ Studies in Children Using Standard Reference Range as Comparison } \\
\hline Gupta et al., 1996 [52] & $\mathrm{P}$ & 25 & $\begin{array}{l}\text { Standard } \\
\text { Reference }\end{array}$ & $\begin{array}{l}20 \% \text { of ASD had below normal IgG subclasses (IgG1 in } \\
\qquad 1 ; \operatorname{IgG} 2 \text { in } 1 ; \operatorname{IgG} 3 \text { in } 1 ; \operatorname{IgG} 4 \text { in } 2)\end{array}$ \\
\hline $\begin{array}{l}\text { Stern et al., } \\
2005 \text { [53] }\end{array}$ & $\mathrm{P}$ & $\begin{array}{l}\quad 24 \\
\text { Recurrent } \\
\text { Infections }\end{array}$ & $\begin{array}{l}\text { Standard } \\
\text { Reference }\end{array}$ & No Difference in Total IgG \\
\hline \multicolumn{5}{|c|}{ Studies in Neonates Using Contemporaneous Control Groups for Comparison } \\
\hline $\begin{array}{c}\text { Grether } \\
\text { et al., } 2010[54]\end{array}$ & $\mathrm{R}$ & 213 & $265 \mathrm{TD}$ & $\begin{array}{c}\text { Neonatal Total IgG lower in ASD } \\
\text { Lower IgG Associated with Increased ASD Risk }\end{array}$ \\
\hline $\begin{array}{c}\text { Grether } \\
\text { et al., } 2016 \text { [55] }\end{array}$ & $\mathrm{R}$ & 84 & $\begin{array}{l}159 \mathrm{TD} \\
49 \mathrm{DD}\end{array}$ & Lower IgG Associated with Increased ASD Risk \\
\hline \multicolumn{5}{|c|}{ Studies on Immunoglobulin G Concentrations in the Cerebrospinal Fluid } \\
\hline Young et al., 1977 [56] & $\mathrm{P}$ & 5 & $\begin{array}{l}\text { Standard } \\
\text { Reference }\end{array}$ & IgG in the CSF was normal \\
\hline $\begin{array}{c}\text { Runge } \\
\text { et al., } 2020 \text { [57] }\end{array}$ & $\mathrm{R}$ & 35 & $39 \mathrm{TD}$ & No Difference in CSF IgG Index \\
\hline
\end{tabular}

Overall, of the eight studies that examined serum IgG in children with ASD, two reported higher and one reported lower total IgG while the others found no significant difference. One study found increased IgG2 subclass concentrations and three studies reported higher IgG4 concentrations. No studies reports lower IgG subclasses. However, one study found that lower total IgG concentrations was correlated with increased severity of disruptive behaviors as measured by the $A B C$ [23], while another study found that higher IgG 4 concentrations were significantly associated with an increased severity of social interaction impairments as measured by the Autism Diagnostic Observation Schedule (ADOS) [49]. 
Two studies examined birth samples from archived newborn blood specimens which were obtained from the California Genetic Disease Screening Program and reported that ASD risk was associated with lower total IgG concentrations in the neonatal period $[54,55]$.

The two studies that examined CSF IgG found no significant difference in CSF IgG concentrations or the IgG index as compared to the reference groups [56,57]. However, one study did find increased protein in 33\% of ASD cases and oligoclonal bands in one patient $(3 \%)$ and GAD65 antibodies in two patients $(6 \%)$ in the CSF.

\subsubsection{Meta-Analysis of Immunoglobulin G Concentrations in ASD}

Nine studies used control groups as comparisons with two large studies using neonates while the remainder examined children. Seven studies used TD unrelated controls, while two studies used TD sibling controls and three studies used unrelated DD controls. One study divided the ASD groups into those with autistic disorder and those without autistic disorder but with autism features. Because it is not clear how this latter group would map onto the current definition of ASD, it has not been included in the analysis. One of the two studies examining neonates did not provide descriptive statistics of the immunoglobulin concentrations so the studies could not be combined. Only one study used parents as controls and the two studies that used developmentally delayed control groups studied different immunoglobulin measures, so parents and developmentally delayed controls were not included in the meta-analysis.

Table 2 outlines the pooled mean difference when combining studies using non-sibling and sibling controls separately as well as all studies combined (see Supplementary Table S2 for the number of participants per comparison). Both the pooled mean difference for the non-sibling and combined studies found that total IgG was lower in the ASD group with a confidence interval that did not include zero. However, the meta-analysis models for these pooled mean differences were not significant because of large variation among studies, as manifested by the significant Cochran's $Q$ and DOI plots showing major asymmetry with LFK indexes of 8.80 and 8.99, respectively. Pooled mean difference for IgG 4 subclass was significantly elevated in individuals with ASD for all comparisons, with the comparison between ASD and TD siblings demonstrating significant variability across studies. None of the other IgG subclasses were found to be significantly different between ASD and comparisons groups in the meta-analysis.

Table 2. Meta-analysis of Studies on Immunoglobulin G Concentration in Autism Spectrum Disorder. Pooled mean difference (MD) with 95\% confidence interval, Cochran's Q (Q), Heterogeneity Index $\left(\mathrm{I}^{2}\right)$. Statistics are estimated by inverse variance heterogeneity model. Significant values are Bold. ${ }^{*} p \leq 0.01 ;{ }^{* *} p \leq 0.001$.

\begin{tabular}{|c|c|c|c|c|c|c|c|c|c|}
\hline & \multicolumn{3}{|c|}{ Non-Siblings } & \multicolumn{3}{|c|}{ Siblings } & \multicolumn{3}{|c|}{ All Controls } \\
\hline & $\begin{array}{l}\text { Pooled } \\
\text { MD }\end{array}$ & $\begin{array}{c}\text { Cochran's } \\
Q\end{array}$ & $I^{2}$ & $\begin{array}{l}\text { Pooled } \\
\text { MD }\end{array}$ & $\begin{array}{c}\text { Cochran's } \\
Q\end{array}$ & $\mathrm{I}^{2}$ & $\begin{array}{l}\text { Pooled } \\
\text { MD }\end{array}$ & $\begin{array}{c}\text { Cochran's } \\
Q\end{array}$ & $I^{2}$ \\
\hline Total IgG & $\begin{array}{c}-231 \\
(-223,-238)\end{array}$ & $40 * *$ & $95 \%$ & $\begin{array}{c}49 \\
(-3,101)\end{array}$ & 3.3 & $70 \%$ & $\begin{array}{c}-225 \\
(-217,-233)\end{array}$ & $153 * *$ & $97 \%$ \\
\hline IgG1 & $\begin{array}{c}14 \\
(-45,74)\end{array}$ & 2.2 & $54 \%$ & $\begin{array}{c}17 \\
(-17,51)\end{array}$ & 5.5 & $82 \%$ & $\begin{array}{c}17 \\
(-13,46)\end{array}$ & 7.7 & $61 \%$ \\
\hline IgG2 & $\begin{array}{c}9.2 \\
(-1.0,19.2)\end{array}$ & 0.0 & $0 \%$ & $\begin{array}{c}35.8 \\
(3.5,68.2)\end{array}$ & 5.8 & $83 \%$ & $\begin{array}{c}11.5 \\
(1.9,21.2)\end{array}$ & 8.23 & $64 \%$ \\
\hline IgG3 & $\begin{array}{c}-0.3 \\
(-3.2,2.6)\end{array}$ & 0.4 & $0 \%$ & $\begin{array}{c}0.5 \\
(-3.7,4.7)\end{array}$ & 0.4 & $0 \%$ & $\begin{array}{c}0.0 \\
(-2.4,2.4)\end{array}$ & 0.9 & $0 \%$ \\
\hline IgG4 & $\begin{array}{c}16.6^{* *} \\
(6.7,26.4)\end{array}$ & 0.7 & $0 \%$ & $\begin{array}{c}19.7 * * \\
(12.8,26.5)\end{array}$ & 6.5 * & $84 \%$ & $\begin{array}{c}18.7^{* *} \\
(13.1,24.3)\end{array}$ & 7.4 & $60 \%$ \\
\hline
\end{tabular}




\subsubsection{Summary of Immunoglobulin G Concentrations in ASD}

Overall, studies on IgG abnormalities in ASD suggest that individuals with ASD may have a wider variation in serum IgG concentrations as compared to non-ASD controls. There appears to be preliminary evidence for both depressed total IgG and elevated IgG 4 subclass, both of which appear to have concentrations related to symptomatology. This may suggest two different immune abnormalities in different subsets of patients. However, with only a few large well-controlled studies, it is difficult to make any firm conclusions.

\subsection{The Theraputic Use of IVIG in ASD}

A total of 27 publications were identified which examined the use of IVIG in ASD. Four studies were prospective, controlled studies; six were prospective, uncontrolled studies; 2 were retrospective, controlled studies; and 15 were retrospective, uncontrolled studies (case reports and series).

\subsubsection{Prospective, Controlled Studies}

Four prospective, controlled studies were identified (Table 3). One study used IVIG in children without immune related problems [58] while the children in the other three studies had immune related problems.

Table 3. Prospective Controlled Immunoglobulin G Treatment Studies in Autism Spectrum Disorder. Specific Polysaccharide Antibody Deficiency (SPAD); Common Variable Immunodeficiency (CVID); Aberrant Behavior Checklist (ABC); Not specified (NS).

\begin{tabular}{ccccc}
\hline Study & $\begin{array}{c}\text { Medical } \\
\text { Indication }\end{array}$ & $\begin{array}{c}\text { Autism } \\
\text { Group (N) }\end{array}$ & $\begin{array}{c}\text { IVIG } \\
\text { Treatment }\end{array}$ & Outcomes \\
\hline $\begin{array}{c}\text { Niederhofer, Staffen } \\
\text { et al., 2003 [58] }\end{array}$ & NS & 12 & $400 \mathrm{mg} / \mathrm{kg}$ & $\begin{array}{c}\text { Improvement in all ABC Subscales } \\
\text { and improved drowsiness and activity }\end{array}$ \\
\hline $\begin{array}{c}\text { Jyonouchi, Geng et al., } \\
\text { 2011 [22] }\end{array}$ & SPAD & 10 & NR & $\begin{array}{c}\text { Decreased pro-inflammatory } \\
\text { cytokines (IL-6, IL-12 and IL-23) and } \\
\text { increased TGF- } \$ \text { and sTNFRII }\end{array}$ \\
\hline $\begin{array}{c}\text { Jyonouchi, Geng et al., } \\
\text { 2011 [59] }\end{array}$ & $\begin{array}{c}\text { SPAD in 6 } \\
\text { CVID in 1 }\end{array}$ & 7 & NR & NR \\
$\begin{array}{c}\text { Maltsev and } \\
\text { Yevtushenko 2016 [60] }\end{array}$ & $\begin{array}{c}\text { NK Cell Deficiency; } \\
\text { Reactivated HSV or } \\
\text { Measles Infection }\end{array}$ & 78 & $\begin{array}{c}2 \mathrm{~g} / \mathrm{kg} \text { monthly } \\
\text { for 6 months }\end{array}$ & $\begin{array}{c}\text { Improvement in all ABC } \\
\text { Subscales }\end{array}$ \\
\hline
\end{tabular}

The first study was a DBPC crossover study of a one-time dose of IVIG $0.4 \mathrm{~g} / \mathrm{kg}$ or placebo in 12 children with ASD (age range 4.2 to 14.9 years) and reported significant improvements as rated by parents and teachers in $\mathrm{ABC}$ irritability, hyperactivity, social withdrawal and inappropriate speech. Improvements were also observed in drowsiness and decreased activity on the Symptom Checklist compared to the placebo group. Significant improvements were not observed by physicians as rated by the Children's Psychiatric Rating Scale (CPRS). Of note, none of the ASD children in this study had abnormalities in IgG or IgM concentrations [58].

Three other studies contained control groups who did not receive a placebo. In the first, 10 children with ASD (age not noted) with specific polysaccharide antibody deficiency (SPAD) and hypogammaglobulinemia were treated with an unspecified IVIG dose and compared to 14 non-ASD children with similar immunodeficiency treated with IVIG and 49 ASD and 39 normal children who did not receive treatment. Pro-inflammatory cytokines (IL-6, IL-12 and IL-23) and productions of IL-12 with exposure to phytohemagglutinin/Concanavalin A and IL-17/IFN- $\gamma$ with exposure to phytohemagglutinin decreased, while TGF- $B$ and sTNFR II increased in the children with ASD who received IVIG compared to normal controls. ASD behaviors were not reported in this study [22]. 
In the second study, seven children with ASD and immunodeficiency (one with CVID and six with SPAD) were treated with any unspecified dose of IVIG, but no effects of IVIG were discussed [59].

Finally, in a third study, 78 children with ASD (ages 2-10 years old, 47 boys, 31 girls) were treated with IVIG $2 \mathrm{~g} / \mathrm{kg}$ per month for six months. Characteristics of the treated children were compared to characteristics of a control group of 32 ASD children who received conventional therapy without IVIG. Additionally, changes in the ABC scale were compared to baseline measurements in the treatment group. Inclusion criteria for IVIG treatment included the presence of two to four polymorphisms in folate cycle genes, deficiency in natural killer cells, reactivated herpes and/or measles virus infections, or signs of leukoencephalopathy on a brain MRI. The authors reported "complete elimination of the phenotype of autism spectrum disorders" in 21 (27\%), "marked improvement" in 33 (42) and mild-to-moderate improvements in $23(29 \%)$. Overall, $77(99 \%)$ had some improvement with IVIG. In the 21 children with the most improvements, one (5\%) lost improvements when IVIG was stopped and $12(50 \%)$ who showed mild-to-moderate improvement lost their gains two to four months after completing therapy. Twenty-nine out of 36 patients $(81 \%)$ with epilepsy had improvement in seizures and 49 out of 68 children $(72 \%)$ had improvements in gastrointestinal symptoms [60]. Compared to baseline, the treated group improved in $\mathrm{ABC}$ irritability, hyperactivity, social withdrawal and inappropriate speech.

\subsubsection{Prospective, Uncontrolled Studies}

Six prospective, uncontrolled studies were identified (Table 4); five studies administered IVIG to individuals with ASD who had immune related abnormalities whereas one study used IVIG in patients without immune problems [61].

Table 4. Prospective Uncontrolled Immunoglobulin G Treatment Studies in Autism Spectrum Disorder. Specific Polysaccharide Antibody Deficiency (SPAD); Common Variable Immunodeficiency (CVID); Aberrant Behavior Checklist (ABC); Clinical Global Impression Severity (CGI-S); Clinical Global Impression Improvement (CGI-I); Social Responsiveness Scale (SRS); Children's Communication Checklist-2 (CCC-2); Autism Diagnostic Observation Scheduled (ADOS).

\begin{tabular}{|c|c|c|c|c|}
\hline Study & $\begin{array}{l}\text { Medical } \\
\text { Indication }\end{array}$ & $\begin{array}{l}\text { Autism } \\
\text { Group }\end{array}$ & $\begin{array}{c}\text { IVIG } \\
\text { Treatment }\end{array}$ & Outcomes \\
\hline $\begin{array}{l}\text { Gupta et al., } \\
1996 \text { [52] }\end{array}$ & $\begin{array}{l}\text { IgG deficiency and } \\
\text { others }\end{array}$ & 10 & $\begin{array}{l}0.4 \mathrm{~g} / \mathrm{kg} \text { every } \\
4 \text { weeks for } \\
6 \text { months }\end{array}$ & $\begin{array}{l}\text { No quantitative outcomes } \\
5 \text { with "marked" or "striking" } \\
\text { improvements. } \\
5 \text { with minimal improvements }\end{array}$ \\
\hline $\begin{array}{l}\text { Plioplys } \\
1998[61]\end{array}$ & None & 10 & $\begin{array}{l}154-375 \mathrm{mg} / \mathrm{kg} \\
\text { every } 6 \text { weeks for } \\
1-6 \text { infusions }\end{array}$ & $\begin{array}{l}\text { No quantitative outcomes } \\
1 \text { remarkable, } 4 \text { mild } \\
\text { and } 5 \text { no improvements }\end{array}$ \\
\hline $\begin{array}{l}\text { DelGiudice-Asch } \\
\text { et al., } 1999 \text { [62] }\end{array}$ & $\begin{array}{l}\text { Recurrent } \\
\text { infections }\end{array}$ & 7 & $\begin{array}{l}400 \mathrm{mg} / \mathrm{kg} \text { every } \\
\text { month for } \\
6 \text { months }\end{array}$ & $\begin{array}{l}2 \text { discontinued treatment } \\
\text { No significant changes in several } \\
\text { quantitative symptom scales }\end{array}$ \\
\hline $\begin{array}{l}\text { Oleske } \\
2004[63]\end{array}$ & $\begin{array}{l}\text { Antibody } \\
\text { deficiency }\end{array}$ & 27 & $\begin{array}{l}0.4-1 \mathrm{~g} / \mathrm{kg} \\
\text { every } 3 \text { weeks for } \\
6-18 \text { months }\end{array}$ & $\begin{array}{c}\text { No quantitative outcomes } \\
\text { Less recurrent infections } \\
\text { ASD symptoms improved in } 78 \%\end{array}$ \\
\hline $\begin{array}{l}\text { Melamed et al., } \\
2006[64]\end{array}$ & $\begin{array}{l}\text { Humoral and/or } \\
\text { cellular } \\
\text { immune deficit }\end{array}$ & 12 & $\begin{array}{l}1 \mathrm{~g} / \mathrm{kg} \text { monthly } \\
\text { for } 3 \text { years }\end{array}$ & $\begin{array}{l}\text { Non-standard quantitative outcomes } \\
\text { Drastic reduction in Infections } \\
\text { Improvement in cognition, } \\
\text { communication and social skills }\end{array}$ \\
\hline $\begin{array}{l}\text { Melamed et al. } \\
2018 \text { [65] }\end{array}$ & $\begin{array}{c}\text { Activated CD154 levels } \\
<80 \text {, recurrent } \\
\text { infections or abnormal } \\
\text { lymphocyte } \\
\text { stimulation test or }\end{array}$ & 14 & $\begin{array}{l}1 \mathrm{~g} / \mathrm{kg} \text { every } \\
2-4 \text { weeks for } \\
10 \text { doses }\end{array}$ & $\begin{array}{l}\text { Improvement in CGI-S and CGI-S, SRS, } \\
\text { CCC-2 and ADOS }\end{array}$ \\
\hline
\end{tabular}


In a prospective, open-label study, 10 children (ages three to six years old) with ASD and IgG deficiency or other immune abnormalities were treated with IVIG $(0.4 \mathrm{~g} / \mathrm{kg}$ every four weeks for six months). Four (40\%) showed "marked improvements", one $(10 \%)$ showed "striking improvements" and five $(50 \%)$ had "minimal improvements". Improvements were noted in social interaction, eye contact, echolalia and better response to commands. Speech improvements included better articulation and improved vocabulary. Younger children had more improvements compared to older patients [52].

In another prospective, open-label study, 10 children with ASD without immune problems (four to 15 years old, mean age eight years) received $0.154-0.375 \mathrm{~g} / \mathrm{kg}$ IVIG (mean dose $0.27 \mathrm{~g} / \mathrm{kg}$ ) every six weeks. Six children received four infusions, whereas the other four received one, three, five, and six infusions, respectively. Five $(50 \%)$ did not show improvements, while four $(40 \%)$ had mild improvements in attention and hyperactivity reported by parents but not confirmed by clinicians; parents of these four children decided not to continue IVIG due to the cost and inconvenience. One child $(10 \%)$ who received $0.375 \mathrm{~g} / \mathrm{kg}$ for four infusions had "a very significant amelioration of autistic symptoms"; when the treatment was stopped the improvements were lost over a three-month period [61].

In another prospective, open-label study, seven children with ASD (ages three to six years old) with a history of recurrent infections or seizures were treated with $0.4 \mathrm{~g} / \mathrm{kg}$ of IVIG every month for six months, with five children completing the study. Children were evaluated with Ritvo-Freeman Real Life Rating Scale (RF), Children Yale-Brown ObsessiveCompulsive Scale, Clinical Global Impression Scale (CGI), and the Autism Modification of the NIMH Global Obsessive-Compulsive Scale. Improvement was noted on the RF sensory responses but was considered not significant after Bonferroni correction [62].

In another prospective, open-label study, 27 children with ASD (ages two to 10 years old, median three years) and immune abnormalities were treated with IVIG $0.4-1.0 \mathrm{~g} / \mathrm{kg}$ every three weeks for six to 18 months. Immune abnormalities included IgG deficiency in five (19\%), IgG subclass deficiency in $12(44 \%)$, or recurrent infections that did not respond to conventional therapy with the presence of functional antibody deficiency in 10 $(37 \%)$. With IVIG treatment, improvements in infections were observed in otitis media in $19(70 \%)$, upper respiratory infections in $11(41 \%)$, and sinopulmonary infections in nine (33\%). Parents and physicians reported improvements in ASD symptoms in 21 (78\%) [63].

In another prospective study, 12 children with ASD (age not reported) with either a humoral or cellular immune deficit (or both) were treated with $1.0 \mathrm{~g} / \mathrm{kg}$ of IVIG monthly for three years. All children had a drastic reduction in the number of infections and improvements in cognition, communication, verbal interaction and social skills (1 to 4 point improvements on a scale of 1 to 5) [64].

In a prospective, open-label 30-week study, 14 children with ASD (mean age $7.6 \pm 3.0$ years) and immune abnormalities received $1 \mathrm{~g} / \mathrm{kg}$ of IVIG every two to four weeks for 10 treatments. Immune abnormalities include T or B cell dysfunction, activated CD154 levels $<80$, or abnormal lymphocyte stimulation test and/or recurrent infections. Outcomes were compared to baseline measurements. Significant improvements were observed in CGI-S total score, CGI-I total score, and SRS total score. Significant improvements on Children's Communication Checklist-2 speech and semantics as well as Autism Diagnostic Observation Schedule (ADOS) stereotyped behaviors and restricted interest, communication plus social interaction total, and reciprocal social interaction were found. Statistically significant improvement on the $A B C$ was only found on the hyperactivity subscale. Significant decreases in TNF- $\alpha$ induced by TLR ligands zymosan, flagellin, and lipopolysaccharide were also reported [65].

\subsubsection{Retrospective, Baseline Controlled Case Series with Prospectively Collected Outcomes}

Two case series (Table 5) were identified and are reviewed by year published. All studies used IVIG in ASD patients with immune-related problems. 
Table 5. Retrospective Case Series Immunoglobulin G Treatment Studies in Autism Spectrum Disorder with Prospectively Baseline Controlled Outcome Measures. Aberrant Behavior Checklist (ABC).

\begin{tabular}{ccccc}
\hline Study & $\begin{array}{c}\text { Medical } \\
\text { Indication }\end{array}$ & $\begin{array}{c}\text { Autism } \\
\text { Group (N) }\end{array}$ & $\begin{array}{c}\text { IVIG } \\
\text { Treatment }\end{array}$ & Outcomes \\
\hline $\begin{array}{c}\text { Boris et al., } \\
2005 \text { [66] }\end{array}$ & 6 with IgG Deficiency & 26 & $\begin{array}{c}400 \mathrm{mg} / \mathrm{kg} \text { every } \\
\text { month for } 6 \text { months }\end{array}$ & $\begin{array}{c}\text { Improvements in ABC total and all subscales } \\
22(85 \%) \text { lost gains after stopping IVIG }\end{array}$ \\
\hline $\begin{array}{c}\text { Connery et al., } \\
2018 \text { [19] }\end{array}$ & $\begin{array}{c}\text { Autoimmune } \\
\text { encephalopathy }\end{array}$ & 31 & $\begin{array}{c}0.75-2 \mathrm{~g} / \mathrm{kg} \text { every } \\
2-6 \text { weeks; } 77 \% \\
\text { treated }>1 \text { year }\end{array}$ & Improvements on SRS and ABC scales \\
\hline
\end{tabular}

In a retrospective case series, 26 children with ASD (ages three to 17 years, mean age 6.8 years) and neurodevelopmental regression (mean age 17 months) were treated with $0.4 \mathrm{~g} / \mathrm{kg}$ of IVIG monthly for six months. Only $23 \%$ of treated patients had low immunoglobulin levels. Total ABC score as well as hyperactivity, inappropriate speech, irritability, social withdrawal and stereotypy subscales showed significant improvement. Twenty-two (85\%) lost some improvements when IVIG was stopped [66].

In an open-label study, 31 children with ASD who had evidence of autoimmune encephalopathy (presence of various brain autoantibodies) were treated with $0.75-2 \mathrm{~g} / \mathrm{kg}$ IVIG every two to six weeks; $77 \%$ were treated for more than one year. Significant improvements were observed in SRS total score and cognition and mannerisms subscales and ABC total score and irritability, lethargy, hyperactivity and inappropriate speech subscales [19]. Of interest, this study also found that the anti-Dopamine D2L and anti-tubulin antibodies of the Cunningham panel (Moleculera, Oklahoma City, OK, USA) were predictive of response to IVIG.

\subsubsection{Retrospective, Uncontrolled Case Series}

Three case series (Table 6) were identified and are reviewed by year published. All studies used IVIG in ASD patients with immune-related problems.

Table 6. Retrospective Uncontrolled Case Series. Specific Polysaccharide Antibody Deficiency (SPAD); Aberrant Behavior Checklist (ABC).

\begin{tabular}{|c|c|c|c|c|}
\hline Study & $\begin{array}{c}\text { Medical } \\
\text { Indication }\end{array}$ & $\begin{array}{l}\text { Autism } \\
\text { Group (N) }\end{array}$ & $\begin{array}{c}\text { IVIG } \\
\text { Treatment }\end{array}$ & Outcomes \\
\hline $\begin{array}{c}\text { Knutsen and } \\
\text { Fenton } 1998 \text { [67] }\end{array}$ & $\begin{array}{l}1 \text { with IgG deficiency } \\
3 \text { with intractable } \\
\text { epilepsy }\end{array}$ & 3 & $\begin{array}{l}1.0-1.7 \mathrm{~g} / \mathrm{kg} \\
\text { up to } 11 \mathrm{months}\end{array}$ & $\begin{array}{l}\text { No quantitative outcomes } \\
2 \text { seizure free, } 1 \text { with seizure improved } \\
\text { ASD symptoms improved in } 2 \\
\text { and worsened in } 1\end{array}$ \\
\hline $\begin{array}{l}\text { Jyonouchi et al., } \\
2012 \text { [68] }\end{array}$ & $\begin{array}{l}\text { SPAD } \\
4 \text { with intractable } \\
\text { epilepsy }\end{array}$ & 8 & $\begin{array}{c}0.6-1 \mathrm{~g} / \mathrm{kg} \text { every } \\
3 \text { weeks for } 1-6 \text { years }\end{array}$ & $\begin{array}{l}\text { No quantitative outcomes } \\
\text { Four with seizure improvement } \\
\text { One with cognitive improvements }\end{array}$ \\
\hline $\begin{array}{l}\text { Fadeyi and Li } \\
2018 \text { [69] }\end{array}$ & IgG deficiency & 3 & NR & $\begin{array}{c}\text { No quantitative outcomes } \\
\text { Improvements in ASD } \\
\text { symptoms and IgG and IgM levels }\end{array}$ \\
\hline
\end{tabular}

Three children with ASD and intractable epilepsy defined as at least three seizures per day were treated with $1.0-1.7 \mathrm{~g} / \mathrm{kg}$ of IVIG for up to 11 months. One child had low total IgG and the others had normal IgG levels. Two patients became seizure-free and the third had a reduction in seizures. Two children had improvement in social interaction, communication and behavior. In one child, seizures and ASD symptoms worsened when IVIG was discontinued [67].

Eight children with ASD and SPAD (ages six to 16 years old) who had worsening of cognitive skills and behavioral symptoms with "immune insults" were treated with $0.6-1 \mathrm{~g} / \mathrm{kg}$ of IVIG every three weeks for one to six years. Three children had below normal 
total IgG. Treatment improved recurrent infections. In the four patients with treatment resistant epilepsy, seizures were significantly improved. Overall ASD symptoms were not reported to improve but behavioral exacerbations associated with infections did improve. Parents reported improvement in cognitive skills in one child but standardized clinical outcome measures did not confirm this [68].

Finally, in a retrospective case series, three children with ASD who had IgG deficiency were treated with an unspecified dose of IVIG over five to eight years. Serum IgG and IgM concentrations improved with improvement in immunoglobulin concentrations believed to correlated with an improvement in ASD symptoms [69].

\subsubsection{Retrospective, Uncontrolled Case Reports}

Twelve studies were case reports (Table 7) and described patients with ASD treated with IVIG for mostly immune-mediated conditions, with two publications reporting on the same case $[70,71]$. Indications for IVIG ranged from purely immune conditions to immune related neurological conditions, as well as one case report for neuroleptic malignant syndrome which is not usually believe to be an immune related condition.

Table 7. Retrospective Uncontrolled Case Studies of Immunoglobulin G Treatment in Autism Spectrum Disorder. Chronic inflammatory Demyelinating Polyneuropathy (CIDP); Common Variable Immunodeficiency (CVID); N-Methyl-D-Aspartic Acid (NMDA); Nicotinic Acetylcholine Receptor (nAChR); Not Reported (NR), month old (mo), years old (yo).

\begin{tabular}{|c|c|c|c|c|}
\hline Study & $\begin{array}{l}\text { Medical } \\
\text { Indication }\end{array}$ & Participant & $\begin{array}{c}\text { IVIG } \\
\text { Treatment }\end{array}$ & $\begin{array}{c}\text { Outcomes } \\
\text { (Non-Quantitative) }\end{array}$ \\
\hline \multicolumn{5}{|c|}{ Immune Abnormality } \\
\hline $\begin{array}{c}\text { Suez and } \\
\text { Scharnwebber } \\
1997[72]\end{array}$ & CVID & 15 yo boy & NR & $\begin{array}{c}\text { Significant improvement in ASD } \\
\text { symptoms }\end{array}$ \\
\hline $\begin{array}{l}\text { Wang et al., } \\
2005 \text { [73] }\end{array}$ & CVID & 22 yo man & $\begin{array}{l}\text { Monthly } \\
\text { Dose NR }\end{array}$ & $\begin{array}{l}\text { Significant improvements in appetite, } \\
\text { weight gain, and serious infections }\end{array}$ \\
\hline $\begin{array}{l}\text { Salehi Sadaghiani } \\
\text { et al., } 2013 \text { [74] }\end{array}$ & CVID & 13 yo boy & NR & No improvements reported \\
\hline \multicolumn{5}{|c|}{ Inflammatory Neuropathy } \\
\hline $\begin{array}{l}\text { Sommerville } \\
\text { et al., } 2007 \text { [75] }\end{array}$ & $\begin{array}{c}\text { CIDP } \\
\text { Epilepsy }\end{array}$ & 8 yo boy & $0.4 \mathrm{~g} / \mathrm{kg} / \mathrm{d}$ for 5 day & No improvements reported \\
\hline $\begin{array}{l}\text { Kamata } \\
\text { et al., } 2017 \text { [76] }\end{array}$ & $\begin{array}{l}\text { Inflammatory } \\
\text { Neuropathy }\end{array}$ & 6 yo girl & $0.4 \mathrm{~g} / \mathrm{kg} / \mathrm{d}$ for 5 day & $\begin{array}{l}\text { Neuropathy improved } \\
\text { No mention of changes in ASD symptoms }\end{array}$ \\
\hline \multicolumn{5}{|c|}{ Immune Mediated Encephalopathy } \\
\hline $\begin{array}{l}\text { Scott et al., } \\
2014 \text { [77] }\end{array}$ & $\begin{array}{l}\text { anti-NMDA receptor } \\
\text { encephalitis }\end{array}$ & 33 mo boy & $0.4 \mathrm{~g} / \mathrm{kg} / \mathrm{d}$ for 5 day & Language and social skills improved \\
\hline $\begin{array}{l}\text { Menon et al., } \\
2014 \text { [79] }\end{array}$ & $\begin{array}{l}\text { anti-nAChR receptor } \\
\text { encephalitis }\end{array}$ & 5 yo boy & $\mathrm{w} /$ plasmapheresis & $\begin{array}{l}\text { Improvements in hyperactivity, agitation, } \\
\text { speech, and social interaction }\end{array}$ \\
\hline $\begin{array}{l}\text { Akcakaya et al., } \\
2015,2016[70,71]\end{array}$ & $\begin{array}{l}\text { Enterovirus } \\
\text { Encephalitis, } \\
\text { Seizures }\end{array}$ & 14 yo girl & $0.02 \mathrm{~g} / \mathrm{kg}$ & $\begin{array}{l}\text { Improvements in eye contact, speech, } \\
\text { communication, and seizures }\end{array}$ \\
\hline $\begin{array}{l}\text { Gonzalez-Toro } \\
\text { et al., } 2013 \text { [78] }\end{array}$ & $\begin{array}{l}\text { anti-NMDA receptor } \\
\text { encephalitis }\end{array}$ & 5 yo boy & $\begin{array}{l}0.4 \mathrm{~g} / \mathrm{kg} / \text { day for } \\
5 \text { days }\end{array}$ & $\begin{array}{l}\text { Improvements in ASD } \\
\text { symptoms and language }\end{array}$ \\
\hline $\begin{array}{l}\text { Bouboulis and } \\
\text { Mast } 2016[80]\end{array}$ & $\begin{array}{l}\text { Autoimmune } \\
\text { Encephalopathy }\end{array}$ & 5 yo boy & $\begin{array}{l}1.6 \mathrm{~g} / \mathrm{kg} \text { every } \\
8 \text { weeks for } 2 \text { years }\end{array}$ & $\begin{array}{c}\text { Improvements in ASD symptoms, } \\
\text { language, } \\
\text { learning, and memory }\end{array}$ \\
\hline \multicolumn{5}{|c|}{ Other Conditions } \\
\hline $\begin{array}{l}\text { Xu et al., } \\
2017[81]\end{array}$ & $\begin{array}{c}\text { Neuroleptic } \\
\text { malignant syndrome }\end{array}$ & 32 yo man & NR & $\begin{array}{l}\text { Seizures and dysautonomia improved } \\
\text { No mention of changes in ASD symptoms }\end{array}$ \\
\hline
\end{tabular}

Three case reports describe individuals with ASD and immune conditions. A 15-yearold boy with ASD and CVID treated with IVIG was reported to have resolution of recurrent 
infections and marked improvement in ASD symptoms [72]. A 22-year-old man with ASD with a large mesenteric granulomatous mass and CVID was treated with monthly IVIG. Appetite, weight and serious infections improved but no changes in ASD behaviors were mentioned [73]. Finally, a 13-year-old boy with ASD and CVID with recurrent infections was treated with IVIG but he continued to have infections and no note was made of changes in ASD behaviors [74].

Two cases of patients with inflammatory neuropathies were reported. An eight-yearold boy with ASD, epilepsy and chronic inflammatory demyelinating polyneuropathy (CIDP) was treated with IVIG and IV methylprednisolone, but weakness progressed. No mention was made of any changes in ASD symptoms with IVIG [75]. A six-year-old girl with ASD and right upper arm weakness due to a demyelinating neuropathy was treated with one course of IVIG with resolution of the neuropathy symptoms but no mention if ASD symptoms improved [76].

Five cases of immune mediated encephalopathy were reported with four of the cases being autoimmune encephalopathy. A 33-month-old boy with ASD and neurodevelopmental regression was diagnosed with anti-N-Methyl-D-aspartic acid (NMDA) receptor encephalitis by lumbar puncture. Treatment with $2 \mathrm{~g} / \mathrm{kg}$ of IVIG over five days resulted in improvements in language and social skills on the third treatment day [77]. A five-yearold ASD girl diagnosed with anti-NMDA receptor encephalitis by lumbar puncture was treated with $20 \mathrm{mg} / \mathrm{kg} /$ day of IV steroids for five days, $0.4 \mathrm{~g} / \mathrm{kg}$ of IVIG for five days and $0.375 \mathrm{~g} / \mathrm{kg}$ of rituximab weekly for four weeks. Improvements were noted in seizures and language with this combination [78]. A five-year-old boy experiencing neurodevelopmental regression with the emergence of ASD symptoms including social isolation and repetitive behaviors was diagnosed with autoimmune encephalitis due to alpha-3 subunit nicotinic acetylcholine receptor autoantibodies. Treatment with plasmapheresis followed by monthly IVIG resulted in significant improvements after five months with the child being able to attend a regular classroom, resolution of hyperactivity and improvements in social interaction [79]. A five-year-old ASD boy with infection-induced autoimmune encephalopathy was treated with $1.6 \mathrm{~g} / \mathrm{kg}$ of IVIG every eight weeks for two years, resulting in marked improvements in social interaction, language, learning and memory; he maintained the cognitive improvements when IVIG was stopped [80]. Lastly, a 14-year-old previously healthy girl with neurodevelopmental regression and the development of ASD symptoms including lack of eye contact, impaired communication, and social withdrawal with the onset of seizures was found to have enterovirus encephalitis as well as a low IgG index in the CSF. Treatment with $20 \mathrm{mg} / \mathrm{kg}$ of IVIG for five days resulted in improvements in eye contact, speech, and communication, as well as a resolution of her seizures [70,71].

Finally, a 32-year-old man with ASD and mental retardation diagnosed with neuroleptic malignant syndrome and seizures was treated with IVIG after he failed multiple anti-epileptics. Two weeks later, his seizures and dysautonomia resolved; no mention was made if ASD symptoms improved [81].

\subsubsection{Meta-Analysis of Behavioral Responses to Intravenous Immunoglobulin}

Five studies used the ABC instrument as an outcome measure, but only two studies provided information to obtain means and standard deviations before and after the treatments to combine outcome measures. Both retrospective studies obtained data prospectively with baseline measurements $[19,66]$. Two other studies also observed changes in $\mathrm{ABC}$ scores from baseline but one did not report any variation measure [60] and the other reported range as a measure of variation [65]. The DBPC crossover study [58] is not appropriate to combine with the open-label studies because of the differences in methodology. Thus, two studies with a total of 46 participants with two sets of measurements for each participant (baseline and treatment) were included in the meta-analysis.

$\mathrm{ABC}$ irritability and total score were found to significantly improve with IVIG with a large effect size [total: $\mathrm{d}^{\prime}=0.80(0.37,1.23), p<0.001$; irritability: $\mathrm{d}^{\prime}=0.87(0.44,1.31)$, $p<0.0001]$. ABC social Withdrawal and hyperactivity were found to significantly im- 
prove with IVIG treatment with a medium effect size [social withdrawal: $\mathrm{d}^{\prime}=0.54(0.12$, $0.95), p=0.01$; hyperactivity: $\left.\mathrm{d}^{\prime}=0.67(0.25,1.09), p=0.001\right]$. ABC stereotyped movements and inappropriate speech were not found to significantly improve when the studies were combined.

Two studies $[19,65]$ used the SRS as an outcome measure but one study reported range as a variation measure [65], so these studies could not be combined.

\subsection{Adverse Effects}

Most studies did not report any AEs. One case series specifically reported that no AEs were observed. None of the prospective controlled studies reported AEs. Two prospective uncontrolled studies reported AEs. Melamed et al. (2018) reported that four (29\%) had infusion site reactions and three (21\%) had a headache. Connery et al. (2018) reported AEs, mostly during the infusion, with headaches in $39 \%$, vomiting in $29 \%$, worsening behaviors in $16 \%$, anxiety in $13 \%$, fever in $13 \%$, nausea in $10 \%$, fatigue in $10 \%$, and rash in 5\%; two (6\%) patients discontinued IVIG because of AEs. One case report reported agitation, combative behavior, and fearfulness [80]. None of the other case reports reported AEs. Thus, the majority of studies did not report AEs, but most studies were not specifically designed to follow AEs as outcome measurements and none of the studies were designed to measure safety. As most of the AEs of IVIG are well known, many AEs may have been considered part of the standard treatment. Most of the AEs reported are consistent with standard IVIG treatment.

\section{Discussion}

This systemic review aimed to identify studies examining IgG concentrations and the use of IVIG in individuals with ASD. We identified 12 studies which examined IgG concentrations and 27 studies that described the use of IVIG in ASD (one study fell into both categories). We found limited evidence for changes in immunoglobulin concentrations in children with ASD, suggesting this might be present in subgroups of children with more severe ASD. Evidence for the effectiveness of IVIG treatment was also found but studies demonstrated many limitations. In most cases, IVIG was used to treat immune abnormalities in individuals with ASD as IVIG is a common, safe and well-tolerated treatment for immune disorders.

Nine of the 12 studies examining IgG concentrations included controls, with two using sibling controls and seven using non-related controls; one study used parents as comparisons and three used non-ASD developmentally delayed controls as a comparison group. One study found that total IgG and IgG4 concentrations were higher in ASD as compared to sibling controls, while the other sibling study demonstrated no differences between those with and without ASD. In studies with non-related control children, two studies demonstrated elevated IgG and IgG4 concentrations in ASD as compared to controls, with one study finding that higher IgG4 concentrations were associated with more severe social interaction impairments in those with ASD. Three studies demonstrated lower IgG in ASD as compared to non-related controls; one study demonstrated a significantly lowered median IgG concentration in ASD as compared to controls, with the depression in IgG concentration related to more severe aberrant behaviors. One study demonstrated that $20 \%$ of children with ASD had subclass deficiency, including two with IgG4 deficiency, and another study demonstrated a lower IgG concentration in the neonatal period for those who went on to be diagnosed with ASD, with neonatal IgG concentration significantly related to the risk of developing ASD. Two studies demonstrated no differences in serum IgG concentrations between ASD and control participants, while another study demonstrated no difference in the CSF IgG index between ASD and control individuals.

Overall, immunoglobulin studies in ASD reveal two patterns of IgG alterations. Three studies demonstrate depressed total IgG levels and three studies demonstrated elevated $\operatorname{IgG}$ concentrations which were primary driven by elevated IgG4 concentrations. Interesting, both abnormalities were correlated with more severe ASD-related symptoms. The meta- 
analysis was consistent with this pattern but also demonstrated significant variability among studies which would be expected if there are subgroups of children with different immunological profiles.

Meta-analysis demonstrated a trend toward lower total IgG concentrations in children with ASD as a group with a large variation in this finding across studies. Several lines of evidence support the notion that this finding is driven by a subgroup of children with ASD and hypogammaglobulinemia rather than simple biological variability. First, a lower total IgG concentration has been found to be correlated with more severe aberrant behaviors in the only large study to examine this relationship [23]. Second, studies on neonates suggest that lower IgG levels were associated with an increased risk for developing ASD $[54,55]$. Third, treatment studies have suggested that treatment of children with ASD and hypogammaglobulinemia results in improved ASD symptoms [52,63,64,66,67,69].

The fact that low total IgG levels in the neonatal period is associated with the development of ASD may suggest that the humoral immune system may be depressed early in life. Consistent with humoral immune system abnormalities, children with ASD are more likely to have recurrent viral and bacterial infections. For example, a history of otitis media (OM) and antibiotic use is associated with increased risk of ASD [82]; children with ASD are more likely to have OM, especially complicated OM, suggesting more severe OM infections [83], as compared to non-ASD siblings; children with ASD are more likely to have recurrent $\mathrm{OM}$ and upper respiratory and other infections [5,84]; and those children with ASD who have recurrent infections are found to be more medically complex and lower functioning [84]. Recurrent infections could be linked to depressed immune response. Studies have suggested that children with ASD and recurrent infections and other immune abnormalities have associated abnormal Toll-like receptor responses [85], dysregulation of inflammatory and counterregulatory cytokines [86], changes in regulatory microRNA [17], and atypical mitochondrial respiration [16].

Meta-analysis has demonstrated that elevation in IgG 4 subclass is related to ASD. Although commonly associated IgG4-related disease, such as fibro-inflammatory changes in the salivary and lacrimal glands, orbit, pancreas, and kidneys [87] is not common for children with ASD, elevated IgG4 is associated with eosinophilic esophagitis [88], a disorder that is under diagnosed and associated with restricted feeding in ASD [89]. This raises the possibility that IgG4 could potentially be used to help differentiate children with feeding disorders due to eosinophilic esophagitis and behavioral issues. Clearly this is an important and promising area of research.

Interestingly, eosinophilic esophagitis is associated with IgE-mediated food allergies which is associated with enteric microbiome alterations in non-ASD children [90,91]. As microbiome imbalances have been associated with ASD [92] and may have important consequences in immune regulation [93], microbiome alterations may be playing a role in immune dysregulation in ASD. The fact that chronic gastrointestinal symptoms have also been linked to non-IgE-mediated food allergies [94] and immune dysregulation [85] in children with ASD demonstrates the complex relationship between gastrointestinal symptoms and immune dysfunction in ASD and the complicated nature of management and treatment of ongoing symptoms in ASD.

Studies which have been conducted on measuring IgG in ASD have been innovative in examining IgG concentrations prior to symptom onset to help understand the role of immune dysfunction in the etiology of ASD and in examining their parents given the research that suggests a transgenerational effect in the etiology of ASD. Clearly, further studies will be needed to better understand the potential subgroups of children with ASD and immune abnormalities, especially with respect to the developmental nature of IgG concentrations. These studies point to the possibility of subsets of children with ASD with different immune profiles, but further studies are needed to verify these abnormalities.

There were four prospective controlled studies of IVIG but only one of these was a DBPC study [58] and only two examined changes in ASD symptoms, with both studies reporting improvements. One of these aforementioned studies enrolled children with 
immune abnormalities while the other did not. One of the other two studies which did not examine changes in symptoms instead measured changes in cytokines with IVIG. The limited number of controlled and placebo-controlled studies is disappointing but given the risk-benefit of an intravenous treatment in children, a high level of certainty of the efficacy is needed before such studies are launched, so the lack of such studies is understandable at this time. More studies will be necessary for future evaluation of this treatment.

Six studies were prospective without a control group with five of the studies enrolling children with ASD and immune problems. Immune problems varied widely from recurrent infections to quantitatively diagnosed immune deficiencies. All studies reported improvements but in one study the improvements were not statistically significant after correction for multiple comparisons. Unfortunately, only two of the six studies used standardized clinical outcome measures to document improvements.

Two studies were retrospective case series of prospectively collected outcomes with both studies using the $\mathrm{ABC}$ questionnaire, allowing the combining of these studies in a meta-analysis, which demonstrated improvements on the ABC scale including significant improvements in irritability, hyperactivity, and social withdrawal, as well as total aberrant behaviors (all with medium to large effect sizes).

Three case series and twelve case reports described treatment of children with ASD with IVIG. Only one study used standardized quantitative clinical outcome measures and all studies which reported changes in ASD symptoms reported improvements. Only one case report and one case series enrolled patients without immune-related problems.

One of the major limitations of the IVIG treatment studies was the lack of standardized outcome measures. The most commonly used standardized outcome measure was the ABC, which was used in five studies, all of which demonstrated improvement in aberrant behaviors. The next most commonly used standardized outcome measure was the SRS in two studies, both of which demonstrated improvements in social function. Other studies noted clinical improvements in communication, irritability, hyperactivity, cognition, attention, social interaction, eye contact, echolalia, speech, and responsiveness, although standardized measures were not always used to collect these observations. Besides improvements in ASD symptoms, other benefits were seen from IVIG. Six studies reported improvements in seizures with IVIG $[60,67,68,76,78,81]$, with one study reporting a worsening of seizures when IVIG was stopped [67]. Other studies demonstrated improvements in recurrent infections [64,73], appetite [73], weight gain [73], neuropathy [76], dysautonomia [81], pro-inflammatory cytokines [22], and gastrointestinal symptoms [60].

The dose of IVIG varied widely from $20 \mathrm{mg} / \mathrm{kg}$ to $2 \mathrm{~g} / \mathrm{kg}$ and the treatment duration varied from one total IVIG treatment to recurrent treatment for many years, but most studies did not document the exact dose and frequency of the treatment. Overall, most studies did not report if AEs occurred, and for the four studies that did, the AEs were of limited duration and severity $[19,65,67,80]$.

The biological mechanism by which IVIG has its therapeutic effect was investigated in a limited number of studies. One prospective controlled study [22] and one prospective uncontrolled study [65] found a decrease in inflammatory cytokines, and one case series demonstrated an improvement in IgG and IgM concentrations [69] with IVIG treatment. Given that IgG and IgM [23] and inflammatory cytokine [17] concentrations have been associated with ASD behaviors, modulation of these factors could play a role in the therapeutic effect of IVIG. Two prospective uncontrolled studies $[63,64]$ and two case series $[72,73]$ noted a substantial decrease in the number of infections with IVIG treatment, and one case series noted an improvement in behavioral exacerbations associated with infections [68]. Given that a subgroup of children with ASD have been described with immune abnormalities who have behavioral exacerbation with infections [86], simply improving the number of infections may improve the ability to function and quality of life for some individuals with ASD. The therapeutic effect of IVIG for modulating autoantibodies may have been effective in the case-series [19] and case-studies [70,71,77-80] of patients with ASD and autoimmune encephalopathy caused by anti-NMDA receptor [77,78], anti-nAChR recep- 
tor [79], anti-dopamine receptor [19], and anti-tubulin [19] autoantibodies. Finally, the therapeutic effect of IVIG on seizures may have been therapeutic in the cases described with refractory seizures $[67,68,70,71]$.

Thus, these studies suggest IVIG treatment can be effective for some individuals with ASD, particularly those with underlying immune-related problems. However, many studies had substantial limitations, including a lack of a control group, only qualitative outcomes reported, no standardized reporting of details of dosing and duration of treatment, and no standardized reporting of AEs. Indeed, this does suggest that the majority of the studies are open to bias. Additionally, several studies did not report commonly used measures of variance such as standard deviation or interquartile range, making their data difficult to include in a meta-analysis. Thus, future studies will need to address these limitations in order to provide high quality evidence for the use of IVIG in ASD.

\section{Conclusions}

ASD is a prevalent and life-long neurodevelopmental disorder with no known cure. Standard of care treatments are effective in some individuals but leave many with incomplete recovery. A better understanding of the underlying physiological abnormalities is beginning to emerge with evidence supporting abnormalities in immune function, making the immune system a potential target for treatment. Several common treatments for children with ASD also have effects on the immune system, suggesting that their efficacy in ASD may in part be linked to their effects on modulating immune function [95]. This review provide support for the notion that at least a subset of children with ASD have immune abnormalities, particularly in humoral immunity characterized by abnormal concentrations of immunoglobulins and may respond to the immune modulating effect of IVIG therapy. This study has found that there is limited evidence that some children with ASD have abnormal IgG concentrations, but this may be driven by a subgroup with abnormalities. The other major finding in this meta-analysis was an elevation in IgG4 subclass. Variations in IgG concentration were perhaps related to ASD symptom severity, suggesting that for some individuals with abnormal IgG concentrations, IVIG may be a directly targeted treatment.

Still IVIG has many other clinical effects aside from replacing endogenous IgG. Indeed, IVIG can modulate the immune system and is commonly used in neurological disorders to treat pathophysiological processes involving inappropriate activation of the immune system. IVIG is a common treatment because it is usually well tolerated with minimal and non-serious AEs. Additionally, as compared to other treatments which modulate the immune system, IVIG modulates immune function while also providing immune protection, so concerns for immune suppression and opportunistic infections are minimized.

Overall, IVIG appears to be effective in many children with ASD, particularly in those with identified immune problems. It also appears to be well tolerated. However, the quality of the evidence for the use of IVIG is still below what is commonly accepted for a routinely used treatment with the bulk of the studies being uncontrolled. Many studies demonstrated bias, including selection bias (lack of randomization), performance bias (lack of blinding), detection bias (lack of standardized outcomes), attrition bias (retrospective studies are prone to losing patients to follow-up), and reporting bias (case studies tend to report positive rather than negative outcomes). Thus, the current set of studies presented should be used to design and implement well-controlled, blinded randomized clinical trials in the future. Additionally, the populations used in these studies are very heterogeneous with many different immune system abnormalities, making it hard to determine if there is a particular subset of children with ASD in which the treatment may be most effective. Thus, further identification of biomarkers that can guide treatment will be helpful.

\section{Patents}

No patents to report. 
Supplementary Materials: Following are available online at https://www.mdpi.com/article/10 $.3390 /$ jpm11060488/s1, Figure S1: PRISMA 2020 flow diagram for new systematic reviews which included searches of databases, registers and other sources, Table S1: PRISMA 2020 Checklist, Table S2: Number of Participants for Meta-analysis of studies on immunoglobulin G Concentration in Autism Spectrum Disorder.

Author Contributions: D.A.R. and R.E.F. has drafted and reviewed this manuscript. All authors have read and agreed to the published version of the manuscript.

Funding: This research received no external funding.

Institutional Review Board Statement: Not applicable.

Informed Consent Statement: Not applicable.

Conflicts of Interest: The authors declare no conflict of interest.

\section{References}

1. Maenner, M.J.; Shaw, K.A.; Baio, J.; Washington, A.; Patrick, M.; DiRienzo, M.; Christensen, D.L.; Wiggins, L.D.; Pettygrove, S. Prevalence of Autism Spectrum Disorder Among Children Aged 8 Years-Autism and Developmental Disabilities Monitoring Network, 11 Sites, United States, 2016. Mmwr. Surveill Summ. 2020, 69, 1-12. [CrossRef]

2. Cakir, J.; Frye, R.E.; Walker, S.J. The lifetime social cost of autism: 1990-2029. Res. Autism Spectr. Disord. 2020, $72,101502$. [CrossRef]

3. Rossignol, D.A.; Frye, R.E. Mitochondrial dysfunction in autism spectrum disorders: A systematic review and meta-analysis. Mol. Psychiatry 2012, 17, 290-314. [CrossRef]

4. Rossignol, D.A.; Frye, R.E. Psychotropic Medications for Sleep Disorders in Autism Spectrum Disorders. In Handbook on Autism and Pervasive Developmental Disorde-Assessment, Diagnosis and Treatmeny; Matson, J.L., Sturmey, P., Eds.; Springer Nature: Cham, Switzerland, 2020.

5. Vargason, T.; Frye, R.E.; McGuinness, D.L.; Hahn, J. Clustering of co-occurring conditions in autism spectrum disorder during early childhood: A retrospective analysis of medical claims data. Autism Res. Off. J. Int. Soc. Autism Res. 2019, 12, $1272-1285$. [CrossRef] [PubMed]

6. Holingue, C.; Newill, C.; Lee, L.C.; Pasricha, P.J.; Daniele Fallin, M. Gastrointestinal symptoms in autism spectrum disorder: A review of the literature on ascertainment and prevalence. Autism Res. Off. J. Int. Soc. Autism Res. 2018, 11, 24-36. [CrossRef] [PubMed]

7. Liao, X.; Yang, J.; Wang, H.; Li, Y. Microglia mediated neuroinflammation in autism spectrum disorder. J. Psychiatr. Res. 2020, 130, 167-176. [CrossRef] [PubMed]

8. Anukirthiga, B.; Mishra, D.; Pandey, S.; Juneja, M.; Sharma, N. Prevalence of Epilepsy and Inter-Ictal Epileptiform Discharges in Children with Autism and Attention-Deficit Hyperactivity Disorder. Indian J. Pediatr. 2019, 86, 897-902. [CrossRef] [PubMed]

9. Tilford, J.M.; Payakachat, N.; Kuhlthau, K.A.; Pyne, J.M.; Kovacs, E.; Bellando, J.; Williams, D.K.; Brouwer, W.B.; Frye, R.E. Treatment for Sleep Problems in Children with Autism and Caregiver Spillover Effects. J. Autism Dev. Disord. 2015, 45, 3613-3623. [CrossRef]

10. Rossignol, D.A.; Frye, R.E. A review of research trends in physiological abnormalities in autism spectrum disorders: Immune dysregulation, inflammation, oxidative stress, mitochondrial dysfunction and environmental toxicant exposures. Mol. Psychiatry 2012, 17, 389-401. [CrossRef]

11. Croen, L.A.; Qian, Y.; Ashwood, P.; Daniels, J.L.; Fallin, D.; Schendel, D.; Schieve, L.A.; Singer, A.B.; Zerbo, O. Family history of immune conditions and autism spectrum and developmental disorders: Findings from the study to explore early development. Autism Res. Off. J. Int. Soc. Autism Res. 2019, 12, 123-135. [CrossRef]

12. Wu, S.; Ding, Y.; Wu, F.; Li, R.; Xie, G.; Hou, J.; Mao, P. Family history of autoimmune diseases is associated with an increased risk of autism in children: A systematic review and meta-analysis. Neurosci. Biobehav. Rev. 2015, 55, 322-332. [CrossRef] [PubMed]

13. Ramirez-Celis, A.; Becker, M.; Nuño, M.; Schauer, J.; Aghaeepour, N.; Van de Water, J. Risk assessment analysis for maternal autoantibody-related autism (MAR-ASD): A subtype of autism. Mol. Psychiatry 2021. [CrossRef]

14. Gumusoglu, S.B.; Stevens, H.E. Maternal Inflammation and Neurodevelopmental Programming: A Review of Preclinical Outcomes and Implications for Translational Psychiatry. Biol. Psychiatry 2019, 85, 107-121. [CrossRef]

15. Harville, T.; Rhodes-Clark, B.; Bennuri, S.C.; Delhey, L.; Slattery, J.; Tippett, M.; Wynne, R.; Rose, S.; Kahler, S.; Frye, R.E. Inheritance of HLA-Cw7 Associated With Autism Spectrum Disorder (ASD). Front. Psychiatry 2019, 10, 612. [CrossRef]

16. Jyonouchi, H.; Geng, L.; Rose, S.; Bennuri, S.C.; Frye, R.E. Variations in Mitochondrial Respiration Differ in IL-1B/IL-10 Ratio Based Subgroups in Autism Spectrum Disorders. Front. Psychiatry 2019, 10, 71. [CrossRef]

17. Jyonouchi, H.; Geng, L.; Streck, D.L.; Dermody, J.J.; Toruner, G.A. MicroRNA expression changes in association with changes in interleukin-1ß/interleukin10 ratios produced by monocytes in autism spectrum disorders: Their association with neuropsychiatric symptoms and comorbid conditions (observational study). J. Neuroinflamm. 2017, 14, 229. [CrossRef] [PubMed] 
18. Vargas, D.L.; Nascimbene, C.; Krishnan, C.; Zimmerman, A.W.; Pardo, C.A. Neuroglial activation and neuroinflammation in the brain of patients with autism. Ann. Neurol. 2005, 57, 67-81. [CrossRef] [PubMed]

19. Connery, K.; Tippett, M.; Delhey, L.M.; Rose, S.; Slattery, J.C.; Kahler, S.G.; Hahn, J.; Kruger, U.; Cunningham, M.W.; Shimasaki, C.; et al. Intravenous immunoglobulin for the treatment of autoimmune encephalopathy in children with autism. Transl. Psychiatry 2018, 8, 148. [CrossRef] [PubMed]

20. Frye, R.E.; Sequeira, J.M.; Quadros, E.V.; James, S.J.; Rossignol, D.A. Cerebral folate receptor autoantibodies in autism spectrum disorder. Mol. Psychiatry 2013, 18, 369-381. [CrossRef] [PubMed]

21. Gupta, S.; Samra, D.; Agrawal, S. Adaptive and Innate Immune Responses in Autism: Rationale for Therapeutic Use of Intravenous Immunoglobulin. J. Clin. Immunol. 2010, 30 (Suppl. S1), S90-S96. [CrossRef]

22. Jyonouchi, H.; Geng, L.; Kapoor, S.; Streck, D.; Toruner, G.J.J.o.A.; Immunology, C. Characterization Of Children With Autism Spectrum Disorders (asd) Requiring Intravenous Immunoglobulin (ivig) For Specific Polysaccharide Antibody Deficiency (spad)/hypogammaglobulinemia-Distinct Patterns Of Cytokine Production And Gene Expression Profiles. J. Allergy Clin. Immunol. 2011, 127, AB231. [CrossRef]

23. Heuer, L.; Ashwood, P.; Schauer, J.; Goines, P.; Krakowiak, P.; Hertz-Picciotto, I.; Hansen, R.; Croen, L.A.; Pessah, I.N.; Van de Water, J. Reduced levels of immunoglobulin in children with autism correlates with behavioral symptoms. Autism Res. Off. J. Int. Soc. Autism Res. 2008, 1, 275-283. [CrossRef]

24. Hausman-Kedem, M.; Menascu, S.; Greenstein, Y.; Fattal-Valevski, A. Immunotherapy for GRIN2A and GRIN2D-related epileptic encephalopathy. Epilepsy Res. 2020, 163, 106325. [CrossRef]

25. Geva-Dayan, K.; Shorer, Z.; Menascu, S.; Linder, I.; Goldberg-Stern, H.; Heyman, E.; Lerman-Sagie, T.; Ben Zeev, B.; Kramer, U. Immunoglobulin treatment for severe childhood epilepsy. Pediatr. Neurol. 2012, 46, 375-381. [CrossRef]

26. Gross-Tsur, V.; Shalev, R.S.; Kazir, E.; Engelhard, D.; Amir, N. Intravenous high-dose gammaglobulins for intractable childhood epilepsy. Acta Neurol. Scand. 1993, 88, 204-209. [CrossRef]

27. Schwab, I.; Nimmerjahn, F. Intravenous immunoglobulin therapy: How does IgG modulate the immune system? Nat. Rev. Immunol. 2013, 13, 176-189. [CrossRef] [PubMed]

28. Tha-In, T.; Bayry, J.; Metselaar, H.J.; Kaveri, S.V.; Kwekkeboom, J. Modulation of the cellular immune system by intravenous immunoglobulin. Trends Immunol. 2008, 29, 608-615. [CrossRef] [PubMed]

29. Kaneko, Y.; Nimmerjahn, F.; Ravetch, J.V. Anti-inflammatory activity of immunoglobulin G resulting from Fc sialylation. Science 2006, 313, 670-673. [CrossRef]

30. Kazatchkine, M.D.; Kaveri, S.V. Immunomodulation of autoimmune and inflammatory diseases with intravenous immune globulin. N. Engl. J. Med. 2001, 345, 747-755. [CrossRef]

31. Negi, V.S.; Elluru, S.; Siberil, S.; Graff-Dubois, S.; Mouthon, L.; Kazatchkine, M.D.; Lacroix-Desmazes, S.; Bayry, J.; Kaveri, S.V. Intravenous immunoglobulin: An update on the clinical use and mechanisms of action. J. Clin. Immunol. 2007, 27, 233-245. [CrossRef] [PubMed]

32. Page, M.J.; McKenzie, J.E.; Bossuyt, P.M.; Boutron, I.; Hoffmann, T.C.; Mulrow, C.D.; Shamseer, L.; Tetzlaff, J.M.; Akl, E.A.; Brennan, S.E.; et al. The PRISMA 2020 statement: An updated guideline for reporting systematic reviews. BMJ (Clin. Res. Ed.) 2021, 372, n71. [CrossRef]

33. Higgins, J.P.T.; Altman, D.G.; Sterne, J.A.C. Assessing risk of bias in included studies. In Cochrane Handbook for Systematic Reviews of Interventions, Version 5.1.0 ed.; Higgins, J.P.T., Green, S., Eds.; The Cochrane Collaboration: London, UK, 2011.

34. Schneider, C.K.; Melmed, R.D.; Barstow, L.E.; Enriquez, F.J.; Ranger-Moore, J.; Ostrem, J.A. Oral human immunoglobulin for children with autism and gastrointestinal dysfunction: A prospective, open-label study. J. Autism Dev. Disord. 2006, 36, 1053-1064. [CrossRef]

35. Handen, B.L.; Melmed, R.D.; Hansen, R.L.; Aman, M.G.; Burnham, D.L.; Bruss, J.B.; McDougle, C.J. A double-blind, placebocontrolled trial of oral human immunoglobulin for gastrointestinal dysfunction in children with autistic disorder. J. Autism Dev. Disord. 2009, 39, 796-805. [CrossRef]

36. Gupta, S. Immunological treatments for autism. J. Autism Dev. Disord. 2000, 30, 475-479. [CrossRef] [PubMed]

37. Altman, D.G.; Machin, D.; Bryant, T.N.; Gardner, M.J. Statistics with Confidence, 2nd ed.; BMJ Books: Oxford, UK, 2000.

38. Higgins, J.P.T.; Green, S. Cochrane Handbook for Systematic Reviews of Interventions; Wiley Online Library: Hoboken, NJ, USA, 2008.

39. Doi, S.A.; Barendregt, J.J.; Khan, S.; Thalib, L.; Williams, G.M. Advances in the meta-analysis of heterogeneous clinical trials I: The inverse variance heterogeneity model. Contemp. Clin. Trials 2015, 45, 130-138. [CrossRef] [PubMed]

40. Higgins, J.P.; Thompson, S.G. Quantifying heterogeneity in a meta-analysis. Stat. Med. 2002, 21, 1539-1558. [CrossRef]

41. Higgins, J.P.; Thompson, S.G.; Deeks, J.J.; Altman, D.G. Measuring inconsistency in meta-analyses. BMJ 2003, 327, 557-560. [CrossRef]

42. Barendregt, J.J.; Doi, S.A.; Lee, Y.Y.; Norman, R.E.; Vos, T. Meta-analysis of prevalence. J. Epidemiol. Community Health 2013, 67, 974-978. [CrossRef]

43. Furuya-Kanamori, L.; Barendregt, J.J.; Doi, S.A.R. A new improved graphical and quantitative method for detecting bias in meta-analysis. Int. J. Evid. Based Healthc. 2018, 16, 195-203. [CrossRef]

44. Lipsey, M.; Wilson, D.B. The way in which intervention studies have "personality" and why it is important to meta-analysis. Eval. Health Prof. 2001, 24, 236-254.

45. Senn, S. Trying to be precise about vagueness. Stat Med. 2007, 26, 1417-1430. [CrossRef] [PubMed] 
46. Cohen, J. Statistical Power Analysis for the Behavioral Sciences, 2nd ed.; Lawrence Erlbaum Associates: New York, NY, USA, 1988. [CrossRef]

47. Croonenberghs, J.; Wauters, A.; Devreese, K.; Verkerk, R.; Scharpe, S.; Bosmans, E.; Egyed, B.; Deboutte, D.; Maes, M. Increased serum albumin, gamma globulin, immunoglobulin IgG, and IgG2 and IgG4 in autism. Psychol. Med. 2002, 32, 1457-1463. [CrossRef]

48. Trajkovski, V.; Ajdinski, L.; Spiroski, M. Plasma concentration of immunoglobulin classes and subclasses in children with autism in the Republic of Macedonia: Retrospective study. Croat. Med. J. 2004, 45, 746-749. [PubMed]

49. Enstrom, A.; Krakowiak, P.; Onore, C.; Pessah, I.N.; Hertz-Picciotto, I.; Hansen, R.L.; Van de Water, J.A.; Ashwood, P. Increased IgG4 levels in children with autism disorder. Brain Behav. Immun. 2009, 23, 389-395. [CrossRef]

50. Spiroski, M.; Trajkovski, V.; Trajkov, D.; Petlichkovski, A.; Efinska-Mladenovska, O.; Hristomanova, S.; Djulejic, E.; Paneva, M.; Bozhikov, J. Family analysis of immunoglobulin classes and subclasses in children with autistic disorder. Bosn. J. Basic Med. Sci. 2009, 9, 283-289. [CrossRef] [PubMed]

51. Wasilewska, J.; Kaczmarski, M.; Stasiak-Barmuta, A.; Tobolczyk, J.; Kowalewska, E. Low serum IgA and increased expression of CD23 on B lymphocytes in peripheral blood in children with regressive autism aged 3-6 years old. Arch. Med. Sci. 2012, 8, 324-331. [CrossRef] [PubMed]

52. Gupta, S.; Aggarwal, S.; Heads, C. Dysregulated immune system in children with autism: Beneficial effects of intravenous immune globulin on autistic characteristics. J. Autism Dev. Disord. 1996, 26, 439-452. [CrossRef]

53. Stern, L.; Francoeur, M.J.; Primeau, M.N.; Sommerville, W.; Fombonne, E.; Mazer, B.D. Immune function in autistic children. Ann. Allergy Asthma Immunol. 2005, 95, 558-565. [CrossRef]

54. Grether, J.K.; Croen, L.A.; Anderson, M.C.; Nelson, K.B.; Yolken, R.H. Neonatally measured immunoglobulins and risk of autism. Autism Res. Off. J. Int. Soc. Autism Res. 2010, 3, 323-332. [CrossRef]

55. Grether, J.K.; Ashwood, P.; Van de Water, J.; Yolken, R.H.; Anderson, M.C.; Torres, A.R.; Westover, J.B.; Sweeten, T.; Hansen, R.L.; Kharrazi, M.; et al. Prenatal and Newborn Immunoglobulin Levels from Mother-Child Pairs and Risk of Autism Spectrum Disorders. Front. Neurosci. 2016, 10, 218. [CrossRef]

56. Young, J.G.; Caparulo, B.K.; Shaywitz, B.A.; Johnson, W.T.; Cohen, D.J. Childhood autism. Cerebrospinal fluid examination and immunoglobulin levels. J. Am. Acad. Child Psychiatry 1977, 16, 174-179. [CrossRef]

57. Runge, K.; Tebartz van Elst, L.; Maier, S.; Nickel, K.; Denzel, D.; Matysik, M.; Kuzior, H.; Robinson, T.; Blank, T.; Dersch, R.; et al. Cerebrospinal Fluid Findings of 36 Adult Patients with Autism Spectrum Disorder. Brain Sci. 2020, 10, 355. [CrossRef]

58. Niederhofer, H.; Staffen, W.; Mair, A. Immunoglobulins as an alternative strategy of psychopharmacological treatment of children with autistic disorder. Neuropsychopharmacology 2003, 28, 1014-1015. [CrossRef]

59. Jyonouchi, H.; Geng, L.; Streck, D.L.; Toruner, G.A. Children with autism spectrum disorders (ASD) who exhibit chronic gastrointestinal (GI) symptoms and marked fluctuation of behavioral symptoms exhibit distinct innate immune abnormalities and transcriptional profiles of peripheral blood (PB) monocytes. J. Neuroimmunol. 2011, 238, 73-80. [CrossRef] [PubMed]

60. Maltsev, D.; Yevtushenko, S.J.I.N.J. High-Dose Intravenous Immunoglobulin Therapy Efficiency in Children with Autism Spectrum Disorders Associated with Genetic Deficiency of Folate Cycle Enzymes. Int. Neurol. J. 2016, 2, 35-48. [CrossRef]

61. Plioplys, A.V. Intravenous immunoglobulin treatment of children with autism. J. Child Neurol. 1998, 13, 79-82. [CrossRef] [PubMed]

62. DelGiudice-Asch, G.; Simon, L.; Schmeidler, J.; Cunningham-Rundles, C.; Hollander, E. Brief report: A pilot open clinical trial of intravenous immunoglobulin in childhood autism. J. Autism. Dev. Disord. 1999, 29, 157-160. [CrossRef]

63. Oleske, J. Another view of autism. UMDNJ Res. 2004, Winter, 22-23.

64. Melamed, I.; McDonald, A.; Gonzalez, M.J.C.I. Sa. 46. Autism as a Neuro-Immune Disease-the Benefit Effect of IVIG. Clin. Immunol. 2006, 119, S121. [CrossRef]

65. Melamed, I.R.; Heffron, M.; Testori, A.; Lipe, K. A pilot study of high-dose intravenous immunoglobulin 5\% for autism: Impact on autism spectrum and markers of neuroinflammation. Autism Res. Off. J. Int. Soc. Autism Res. 2018, 11, 421-433. [CrossRef] [PubMed]

66. Boris, M.; Goldblatt, A.; Edelson, S.M. Improvement in children with autism treated with intravenous gamma globulin. J. Nutr. Environ. Med. 2005, 15, 169-176. [CrossRef]

67. Knutsen, A.P.; Fenton, G. High-dose intravenous immunoglobulin therapy in three children with seizure disorders and autistic features. Pediatr. Asthma Allergy Immunol. 1998, 12, 213-216. [CrossRef]

68. Jyonouchi, H.; Geng, L.; Streck, D.L.; Toruner, G.A. Immunological characterization and transcription profiling of peripheral blood (PB) monocytes in children with autism spectrum disorders (ASD) and specific polysaccharide antibody deficiency (SPAD): Case study. J. Neuroinflamm. 2012, 9, 4. [CrossRef]

69. Fadeyi, M.; Li, T.J.J.o.D.A. Evaluating possible use of IVIG in autism spectrum disorder (ASD). J. Drug Assess. 2018, 7, 14 [CrossRef]

70. Akcakaya, N.H.; Tekturk, P.; Cagatay, A.; Tur, E.K.; Yapici, Z. Atypical enterovirus encephalitis causing behavioral changes and autism-like clinical manifestations: Case report. Acta Neurol. Belg. 2016, 116, 679-681. [CrossRef]

71. Akcakaya, H.; Tekturk, P.; Tur, E.K.; Eraksoy, M.; Yapici, Z. P103-2340: Atypical enterovirus encephalitis causing behavioral changes and autism-like clinical manifestations: Case report. Eur. J. Paediatr. Neurol. 2015, 19, S123. [CrossRef] 
72. Suez, D.; Scharnwebber, K. Intravenous Immunoglobulin (IVIG) Therapy in an Autistic Child with Common Variable Immune Deficiency (CVID)-Case Report. J. Allergy Clin. Immunol. 1997, 99, S2.

73. Wang, J.; Rodriguez-Davalos, M.; Levi, G.; Sauter, B.; Gondolesi, G.E.; Cunningham-Rundles, C. Common variable immunodeficiency presenting with a large abdominal mass. J. Allergy Clin. Immunol. 2005, 115, 1318-1320. [CrossRef] [PubMed]

74. Salehi Sadaghiani, M.; Aghamohammadi, A.; Ashrafi, M.R.; Hosseini, F.; Abolhassani, H.; Rezaei, N. Autism in a child with common variable immunodeficiency. Iran J. Allergy Asthma Immunol. 2013, 12, 287-289. [PubMed]

75. Sommerville, L.; Cordeiro, N.; McHenry, P.; O’Regan, M. CBP012 Chronic demyelinating neuropathy with multiple vitamin deficiencies in a child with autism. Eur. J. Paediatr. Neurol. 2007, 11, 89. [CrossRef]

76. Kamata, A.; Muramatsu, K.; Sawaura, N.; Makioka, N.; Ogata, T.; Kuwashima, M.; Arakawa, H. Demyelinating neuropathy in a 6-year-old girl with autism spectrum disorder. Pediatr. Int. Off. J. Jpn. Pediatr. Soc. 2017, 59, 951-954. [CrossRef]

77. Scott, O.; Richer, L.; Forbes, K.; Sonnenberg, L.; Currie, A.; Eliyashevska, M.; Goez, H.R. Anti-N-methyl-D-aspartate (NMDA) receptor encephalitis: An unusual cause of autistic regression in a toddler. J. Child Neurol. 2014, 29, 691-694. [CrossRef]

78. Gonzalez-Toro, M.C.; Jadraque-Rodriguez, R.; Sempere-Perez, A.; Martinez-Pastor, P.; Jover-Cerda, J.; Gomez-Gosalvez, F. [Anti-NMDA receptor encephalitis: Two paediatric cases]. Rev. Neurol. 2013, 57, 504-508. [PubMed]

79. Menon, D.U.; Garg, A.; Chedrawi, A.K.; Pardo, C.A.; Johnston, M.V. Subacute encephalitis in a child seropositive for alpha-3 subunit of neuronal nicotinic acetylcholine receptors antibody. J. Pediatr. Neurol. 2014, 12, 161-166.

80. Bouboulis, D.A.; Mast, P.A. Infection-Induced Autoimmune Encephalopathy: Treatment with Intravenous Immune Globulin Therapy. A Report of Six Patients. Int. J. Neurol. Res. 2016, 2, 256-258. [CrossRef]

81. Xu, Z.; Prasad, K.; Yeo, T. Progressive Encephalomyelitis with Rigidity and Myoclonus in an Intellectually Disabled Patient Mimicking Neuroleptic Malignant Syndrome. J. Mov. Disord. 2017, 10, 99-101. [CrossRef] [PubMed]

82. Wimberley, T.; Agerbo, E.; Pedersen, C.B.; Dalsgaard, S.; Horsdal, H.T.; Mortensen, P.B.; Thompson, W.K.; Köhler-Forsberg, O.; Yolken, R.H. Otitis media, antibiotics, and risk of autism spectrum disorder. Autism Res. Off. J. Int. Soc. Autism Res. 2018, 11, 1432-1440. [CrossRef]

83. Adams, D.J.; Susi, A.; Erdie-Lalena, C.R.; Gorman, G.; Hisle-Gorman, E.; Rajnik, M.; Elrod, M.; Nylund, C.M. Otitis Media and Related Complications Among Children with Autism Spectrum Disorders. J. Autism Dev. Disord. 2016, 46, 1636-1642. [CrossRef]

84. Mason-Brothers, A.; Ritvo, E.R.; Freeman, B.J.; Jorde, L.B.; Pingree, C.C.; McMahon, W.M.; Jenson, W.R.; Petersen, P.B.; Mo, A. The UCLA-University of Utah epidemiologic survey of autism: Recurrent infections. Eur. Child Adolesc. Psychiatry 1993, 2, 79-90. [CrossRef]

85. Jyonouchi, H.; Geng, L.; Cushing-Ruby, A.; Quraishi, H. Impact of innate immunity in a subset of children with autism spectrum disorders: A case control study. J. Neuroinflamm. 2008, 5, 52. [CrossRef]

86. Jyonouchi, H.; Geng, L.; Davidow, A.L. Cytokine profiles by peripheral blood monocytes are associated with changes in behavioral symptoms following immune insults in a subset of ASD subjects: An inflammatory subtype? J. Neuroinflamm. 2014, 11, 187. [CrossRef]

87. Maritati, F.; Peyronel, F.; Vaglio, A. IgG4-related disease: A clinical perspective. Rheumatol. Oxf. Engl. 2020, 59, iii123-iii131. [CrossRef]

88. Lim, A.H.; Wong, S.; Nguyen, N.Q. Eosinophilic Esophagitis and IgG4: Is There a Relationship? Dig. Dis. Sci. 2021. [CrossRef]

89. Heifert, T.A.; Susi, A.; Hisle-Gorman, E.; Erdie-Lalena, C.R.; Gorman, G.; Min, S.B.; Nylund, C.M. Feeding Disorders in Children With Autism Spectrum Disorders Are Associated With Eosinophilic Esophagitis. J. Pediatr. Gastroenterol. Nutr. 2016, 63, e69-e73. [CrossRef]

90. Goldberg, M.R.; Mor, H.; Magid Neriya, D.; Magzal, F.; Muller, E.; Appel, M.Y.; Nachshon, L.; Borenstein, E.; Tamir, S.; Louzoun, Y.; et al. Microbial signature in IgE-mediated food allergies. Genome Med. 2020, 12, 92. [CrossRef]

91. Lee, K.H.; Guo, J.; Song, Y.; Ariff, A.; O'Sullivan, M.; Hales, B.; Mullins, B.J.; Zhang, G. Dysfunctional Gut Microbiome Networks in Childhood IgE-Mediated Food Allergy. Int. J. Mol. Sci. 2021, 22, 79. [CrossRef]

92. Andreo-Martínez, P.; Rubio-Aparicio, M.; Sánchez-Meca, J.; Veas, A.; Martínez-González, A.E. A Meta-analysis of Gut Microbiota in Children with Autism. J. Autism Dev. Disord. 2021. [CrossRef] [PubMed]

93. Roussin, L.; Prince, N.; Perez-Pardo, P.; Kraneveld, A.D.; Rabot, S.; Naudon, L. Role of the Gut Microbiota in the Pathophysiology of Autism Spectrum Disorder: Clinical and Preclinical Evidence. Microorganisms 2020, 8, 1369. [CrossRef] [PubMed]

94. Jyonouchi, H. Food allergy and autism spectrum disorders: Is there a link? Curr. Allergy Asthma Rep. 2009, 9, 194-201. [CrossRef]

95. Thom, R.P.; McDougle, C.J. Immune Modulatory Treatments for Autism Spectrum Disorder. Semin. Pediatr. Neurol. 2020, 35 , 100836. [CrossRef] [PubMed] 